\title{
A DECADE OF PROGRESS IN SEISMOLOGY SINCE THE EDGECUMBE EARTHQUAKE
}

\author{
Euan G C Smith ${ }^{1}$
}

\begin{abstract}
SUMMARY
During the decade, the contemporaneous increase in data from moderately large earthquakes in New Zealand (and overseas) and the re-equipping of the New Zealand seismograph and accelerograph networks has seen good progress on several fronts. Earthquakes are now more accurately located and their spatial distribution is better defined. There have been improvements in the various databases used for seismic hazard assessments: active faults, earthquake catalogues, historical seismicity, and strong ground motions. The increase in strong-motion data has enabled the development of better models for Peak Ground Acceleration, and the effect of site conditions on site response, particularly for weak-tomoderate earthquake motions, has been studied in detail.
\end{abstract}

\section{INSTRUMENTATION SEISMOGRAPHS AND ACCELEROGRAPHS}

The decade since Edgecumbe has seen the substantial reequipping of the networks of accelerographs and seismographs in New Zealand with digitally recording instruments. For the seismograph network this has been a complete refurnishing: all recording is now digital, although some sub-networks use bandlimited analogue telemetry that limits the dynamic range of their digital recordings (e.g. [15]). The new technology has produced a substantial improvement in both the quality and quantity of information about New Zealand's regular seismicity, with the number of events processed per year going from c. 3000 in the mid- 80 s to c. 15,000 by the mid-90s. This has in turn led to a step-change in understanding about the distribution of small earthquakes ([2] - see below).

The installation of more than 60 digital accelerographs during the early nineties has complemented rather than supplanted the existing network of analogue recorders [5]. These installations were very timely as they have enabled a greater volume of genuinely strong-motion data to be collected from the slight increase in numbers of moderately large earthquakes since Edgecumbe (see below), as well as providing data from more of the smaller earthquakes because of the digital instruments' greater sensitivity and storage capacity.

An additional feature of the new technology is the diminishing of the distinction between 'accelerographs' and 'seismographs'. In New Zealand, digital seismograms are direct outputs from velocity transducers. These may be numerically differentiated to give acceleration records, thus supplementing the database of accelerograms for attenuation studies. Projects to use this combined database for improved attenuation models are underway (e.g. [18]). Moreover, the most modern seismological recording technology is the so-called broad-band seismograph, which uses as a

Inst. of Geophysics, Victoria University of Wellington (Fellow \& Ex-President) sensor a force-balance accelerometer and then employs carefully designed and stabilised electronics to give flat acceleration responses from $20 \mathrm{~Hz}$ to as much as $1000 \mathrm{~s}$. Few of these expensive instruments have been deployed in New Zealand to date, but development plans for the seismograph network envisage their acquisition, leading to improvements in both earthquake studies and attenuation models.

\section{DISTRIBUTION OF SEISMICITY}

The new seismograph network, with stations located at sites subject to less natural and cultural noise than the old network has lead to more accurate locations which has brought the pattern of regularly occurring small earthquakes into sharper focus [2]. In particular, the shallow seismicity of the South Island away from the subduction zones is revealed to be more concentrated into zones of activity, some of which are linear and parallel to active faults. In the North Island, the better resolved earthquake locations produce a clearer image of the subducted Pacific plate which lies between $15-30 \mathrm{~km}$ below the eastern North Island before deepening under the axial ranges. Projects to incorporate this better defined seismicty into hazard models are underway.

\section{LESSONS FROM LARGER EARTHQUAKES - NEW ZEALAND AND OVERSEAS}

As well as its social and economic impact, the Edgecumbe earthquake was the first earthquake since the 1968 Inagahua earthquake to be sufficiently large and accessible to allow a comprehensive geological, geodetic and seismological study using the technology of the day [23], [1], [3]. Since then New Zealand has seen a mild increase in the number of shallow (depth less than $50 \mathrm{~km}$ ) magnitude 6 and greater earthquakes to about the long-term average rate of one per year (excluding aftershocks). 
TABLE 1

Magnitude 5.8 and greater New Zealand earthquakes, depth $\leq 50$ 1987-1995 *

$\begin{array}{llllrl}\text { Event } & \text { Date } & \text { Latitude S } & \text { Longitude E } & \text { Depth km } & \text { Mag. ML } \\ \text { Edgecumbe [5] } & 2 / 3 / 87 & 37.92 & 176.76 & 8 & 6.3 \text { MS 6.6 } \\ \text { Doubtful Sound } & 31 / 5 / 89 & 45.33 & 166.87 & 23 & 6.1 \\ \text { Lake Tennyson } & 10 / 2 / 90 & 42.25 & 172.65 & 13 & 5.8 \\ \text { Weber I } & 19 / 2 / 90 & 40.47 & 176.44 & 34 & 5.9 \\ \text { Weber II } & 13 / 5 / 90 & 40.43 & 176.47 & 30 & 6.2 \\ \text { Hawks Crag I } & 28 / 1 / 91 & 41.89 & 171.61 & 5 & 6.1 \\ \text { Hawks Crag Il } & 28 / 1 / 91 & 41.90 & 171.73 & 17 & 6.3 \\ \text { (Hawks Crag III) } & 15 / 2 / 91 & 42.04 & 171.59 & 7 & 6.0 \\ \text { (Weber III) } & 2 / 3 / 92 & 40.43 & 176.60 & 37 & 5.8 \\ \text { Wilberforce River } & 30 / 3 / 92 & 43.05 & 171.23 & 5 & 5.8 \\ \text { (Bay of Plenty) } & 21 / 6 / 92 & 37.58 & 176.87 & 5 & 6.1 \\ \text { Tikokino } & 11 / 4 / 93 & 39.72 & 176.70 & 35 & 6.1 \\ \text { Secretary Is. } & 10 / 8 / 93 & 45.21 & 166.71 & 5 & 6.7 \\ \text { Ormond } & 10 / 8 / 93 & 38.52 & 177.93 & 48 & 6.3 \\ \text { Arthur's Pass [3] } & 18 / 6 / 94 & 43.04 & 171.45 & 7 & 6.6 \mathrm{Mw} 6.7 \\ \text { Arthur's Pass aftersh. } & 19 / 6 / 94 & 43.19 & 171.50 & 5 & 6.0 \\ \text { Arthur's Pass aftersh. } & 21 / 6 / 94 & 43.29 & 171.25 & 5 & 6.0 \\ \text { (Bay of Plenty) } & 15 / 12 / 94 & 37.27 & 177.53 & 12 & 6.1 \\ \text { East Cape } & 5 / 2 / 95 & 37.65 & 179.45 & 12 & 7.0 \\ \text { East Cape aftershock } & 6 / 2 / 95 & 37.76 & 179.40 & 12 & 6.0 \\ \text { East Cape aftershock } & 6 / 2 / 95 & 37.77 & 179.54 & 12 & 5.8 \\ \text { East Cape aftershock } & 6 / 2 / 95 & 37.89 & 179.42 & 12 & 5.9 \\ \text { East Cape aftershock } & 6 / 2 / 95 & 37.80 & 179.48 & 12 & 5.9 \\ \text { East Cape aftershock } & 10 / 2 / 95 & 37.92 & 179.51 & 12 & 6.5 \\ \text { East Cape aftershock } & 13 / 2 / 95 & 37.46 & 179.14 & 12 & 6.2 \\ \text { East Cape aftershock } & 15 / 2 / 95 & 37.49 & 179.53 & 12 & 5.8 \\ \text { (Arthur's Pass) } & 29 / 5 / 95 & 42.94 & 171.60 & 4 & 6.0 \\ \text { Cass } & 24 / 11 / 95 & 42.95 & 171.82 & 7 & 6.3 \\ & & & & & \end{array}$

* Data from computer catalogue, Inst. Geol. Nucl. Sci. Seismological Observatory, Wellington, unless otherwise referenced.

These events have been the subject of several studies that have improved our understanding of the occurrence of moderately large New Zealand earthquakes, including providing data on the accelerations such earthquakes produce in the near field (e.g [4], [10]).

In addition to these earthquakes, it is worth noting that the postEdgecumbe period has seen, fortuitously, an increase in the number of reconnaissances that the Society has undertaken to similarly sized earthquakes overseas. These earthquakes, and most notably the 1989 Loma Prieta, 1994 Northridge and 1995 Kobe earthquakes, have provoked a substantial number of research projects across the field of seismology and earthquake engineering, and these have usefully complemented the studies of our own earthquakes. For example, the increased volume of Peak Ground Acceleration data from within $100 \mathrm{~km}$ of such earthquakes has produced a number of new PGA attenuation models and comparative studies (e.g. [26]).

\section{HISTORICAL STUDIES - IMPORTANT EARTHQUAKES}

During the decade, a number of research projects have documented New Zealand's important historical earthquakes. Magnitudes for larger earthquakes this century have been revised to make them as consistent as possible [9], and studies are underway to use teleseismically recorded waves to model the nature of the faulting, and estimate the depth, of some of our largest earthquakes. A full compilation on the 1855 Wellington earthquake has been completed (pers. comm. Grapes, R. \& Downes G.) and studies are underway on the 1904, 1931 and 1934 earthquakes.

\section{FAULT STUDIES FOR SEISMIC HAZARD DATA}

One of the consequences of the Edgecumbe Earthquake was a general re-awakening of awareness of New Zealand's earthquake hazard. Consequently there has been an increased demand for seismic hazard assessments and associated studies (e.g. lifelines) particularly at the regional and site level. Since the establishment of DSIR's Earth Deformation Section in the 1970 's, the database of recently active faults has grown steadily, often as a result of commissioned studies, providing a valuable resource for future national and regional seismic hazard assessments. National coverage is understandably a little uneven with greatest attention having been given to areas with high hazard (e.g. Wellington; [13]) or sites with valuable assets.

\section{ATTENUATION STUDIES}

The simultaneous increases in the number of moderately large earthquakes and the demand for hazard and risk assessments have given opportunity and impetus to a number of studies. 


\section{Modified Mercalli (MM) Intensity}

Although MM Intensity has many drawbacks, understanding attenuation of MM Intensity is essential for seismic risk studies because of the unavoidable linkage between MMI values and damage ratios for historical earthquakes. The MM intensity scale has been revised to make it self-consistent and compatible with New Zealand conditions [21], [7], and there have been new models for MM Intensity attenuation produced [6], [19], [20].

\section{Peak Ground Acceleration}

The increase in genuinely strong earthquake motions recorded in New Zealand has seen significant progress in the development of attenuation models for Peak Ground Acceleration and other instrumental measures [16], [10], [26]. These studies have shown that attenuation of PGA in New Zealand is similar to the Japanese model of Fukushima and Tanaka [11] but dissimilar to models for the western USA. The general effect of this difference is that higher PGAs are predicted for New Zealand, especially within $100 \mathrm{~km}$, than in the western USA or Europe.

PGA attenuation studies are often limited by the great scatter in the data. To help ameliorate this, site conditions have been surveyed for New Zealand accelerograph sites [5] which should lead to the development of site corrections for PGA and other measures. However, the use of PGA as a complete characterisation of earthquake impact at a site is demonstrably limited and future research must consider the question of what is or are the most appropriate measure, or measures, of earthquake impact. Studies to determine models of attenuation of spectral acceleration are underway.

\section{MICROZONING}

One of the main research thrusts in earthquake seismology in the last decade, both here and overseas, has been to increase understanding of site effects and responses in earthquakes. Spurred first by the 1985 Mexico City earthquake and then by the 1989 Loma Prieta, research has looked at the problem of site amplification, including amplification of moderate motions at significant distances from the earthquake source, using a wide variety of techniques - geotechnical investigations, strongmotion studies, weak-motion studies using background seismicity and noise sources, and mathematical modelling. In New Zealand, these projects have been successful at identifying and quantifying the hazard enhancement from site effects (e.g. [24], [13]). In addition, New Zealand modelers have been among world leaders in modelling the seismic response of sedimentary basins and topography (e.g. [14]). One of the key findings has been that the actual response at a site in a particular earthquake is very sensitive to subtle geological variations in structure beneath that site, so that another earthquake at another azimuth might provoke a distinctly different response [12]. This partly explains the substantial scatter of data in attenuation studies, and implies that site response cannot be deterministically predicted but requires stochastic modelling. Ongoing research is directed towards understanding the importance of site effects nearer to the source of large earthquakes (e.g. [8]) and to understanding the phenomenon of resonance, which does not occur at all soft-sedimentary basin sites [25].

\section{REFERENCES}

1. Anderson, H.J., Smith, E.G.C, \& Robinson, R. (1990). Normal faulting in a back-arc basin: seismological characteristics of the March 2, 1987, Edgecumbe, New Zealand, earthquake. J. Geophys. Res. 95: 4709-23.

2. Anderson, H.J., \& Webb, T.H. (1994). New Zealand seismicity: patterns revealed by the upgraded National Seismograph Network. N.Z. J. Geol. Geophys. 37: 477-493.

3. Beanland, S., Blick, G.H., \& Darby, D.J. (1990). Normal faulting in a back-arc basin: geological and geodetic investigations of the of the March 2, 1987, Edgecumbe, New Zealand, earthquake. J. Geophys. Res. 95: 4709-23.

4. Cousins, W.J., Hefford, R.T., Baguley, D.E., O'Kane, S.M., McVerry, G.H., \& Porritt, T.E. (1995). Computer analyses of New Zealand earthquake accelerograms 9: the Arthur's Pass earthquake of 18 June 1994. Inst. Geol. Nucl. Sci. Sci. Rep. 95/32. 79 pp plus computer disk.

5. Cousins, W.J., Perrin, N.D., McVerry, G.H., Hefford, R.T., \& Porritt, T.E. (1996). Ground conditions at strong-motion recording sites in New Zealand. Inst. Geol. Nucl. Sci. Sci. Rep. 96/33. 238 pp.

6. Dowrick, D.J. (1991). A revision of attenuation relationships for Modified Mercalli intensity in New Zealand. Bull. N.Z. Nat. Soc. Earthq. Engg. 24: 210-24.

7. Dowrick, D.J. (1996). The Modified Mercalli Intensity Scale - revisions arising from recent studies of New Zealand earthquakes. Bull. N.Z. Nat. Soc. Earthq. Engg. 29: 92106.

8. Dowrick, D.J., Rhoades, D.A., Babor, J., \& Beetham, R.D (1995). Damage ratios for houses and microzoning effects in Napier in the magnitude 7.8 Hawke's Bay, New Zealand earthquake of 1931. Bull. N.Z. Nat: Soc. Earthq. Engg. 28: 134-45.

9. Dowrick, D.J. and Smith, E.G.C. (1990). Surface wave magnitudes of some New Zealand earthquakes 1901-1988. Bull. N.Z. Nat. Soc. Earthq. Engg. 23: 198-210.

10. Dowrick, D.J, \& Sritharan, S. (1993). Attenuation of peak ground accelerations in some recent New Zealand earthquakes. Bull. N.Z. Nat. Soc. Earthq. Engg. 26: 3-13.

11. Fukushima, Y., \& Tanaka, T. (1990). A new attenuation relation for peak ground acceleration of strong ground motion in Japan. Bull. Seism. Soc. Am. 80: 757-83.

12. Haines, A.J., Benites, R., \& Yu, J. (1994). 3-Dimensional modelling of the effects of near-surface ground structure in central Christchurch, New Zealand, on the passage of seismic waves. Report to the Earthquake Commission. Inst. Geol. Nucl. Sciences, Wellington. 66 pp.

13. Kingsbury, P.A. \& Hastie, W.J. (comp.) (1992). Seismic hazard map series: ground shaking hazard, map sheet 3 Lower Hutt (1st Ed.) 1:25,000, with notes. Wellington Regional Council, Wellington. 
14. Marsh, J. Larkin, T.J., Haines, A.J., \& Benites, R.A. (1995). Comparison of linear and non-linear seismic responses of two-dimensional alluvial basins. Bull. Seism. Soc. Am. 85: 874-89.

15. Maunder, D.E. (ed.) (1994). New Zealand Seismological Report 1992. Inst. Geol. Nucl. Sci. Seismological Obs. Bulletin E-176.

16. McVerry, G.H., Dowrick, D.J, Sritharan, S., Cousins, W.J., \& Porritt, T.E. (1993). Attenuation of peak ground accelerations in New Zealand. Proc. Workshop on StrongMotion Data, Menlo Park, USA, 2: 23-38.

17. NZNSEE Study Group (1992). A revision of the Modified Mercalli Seismic Intensity scale. Bull. N.Z. Nat. Soc. Earthq. Engg. 25: 345-357.

18. Pancher, A. in prep. Attenuation of weak ground motion. $\mathrm{MSc}$ thesis, Victoria University of Wellington.

19. Smith, W.D (1995). A development in the modelling of far field intensities for New Zealand earthquakes. Bull. N.Z. Nat. Soc. Earthq. Engg. 28: 196-217.

20. Smith, W.D (1995). A procedure for modelling near-field earthquake intensities. Bull. N.Z. Nat. Soc. Earthq. Engg. 28: 218-223.
21. Study Group NZNSEE. (1992). A revision of the Modified Mercalli Intensity Scale. Bull. N.Z. Nat. Soc. Earthq. Engg. 25: 345-57.

22. Van Dissen, R.J. \& Berryman, K.R. (1996). Surface rupture earthquakes over the last $\sim 1000$ years in the Wellington region, New Zealand, and implications for ground shaking hazard. J. Geophys. Res. 101: 5999-6019.

23. Various authors. (1989). Edgecumbe. N.Z. J. Geol. Geophys. 32. 190 pp.

24. Various authors. (1992). Papers on microzonation of the Hutt Valley. Bull. N.Z. Nat. Soc. Earthq. Engg. 25: 245344.

25. Yu, J. (1996). Observation and synthesis of seismic wavefields in basin structures. $\mathrm{Ph} \mathrm{D}$ thesis. Victoria University of Wellington. $332 \mathrm{pp}$.

26. Zhao, J.X., Dowrick, D.J., \& McVerry, G.H. (1997) Attenuation of peak ground accelerations in New Zealand. Submitted Bull. N.Z. Nat. Soc. Earthq. Engg. 